\title{
Conservation planning: a macroecological approach using the endemic terrestrial vertebrates of the Brazilian Cerrado
}

\author{
José Alexandre Felizola Diniz-Filho, Luis Mauricio Bini, Míriam Plaza Pinto \\ Levi Carina Terribile, Guilherme de Oliveira, Cleiber Marques Vieira \\ Daniel Blamires, Bruno de Souza Barreto, Priscilla Carvalho, Thiago Fernando \\ L.V.B. Rangel, Natalia Mundin Tôrres and Rogério Pereira Bastos
}

\begin{abstract}
Increasing rates of habitat loss and human occupation are creating demands for optimum strategies that maximize conservation efforts, despite the lack of detailed data required for implementation. Broad scale biogeographical data may furnish initial guidelines for conservation planning in a hierarchical framework for establishing conservation priorities and helping guide future research programmes. This approach may be critical in regions for which few detailed data on diversity, abundance and distribution are available, such as in the Cerrado biome of central Brazil. We used a macroecological approach, based on the extent of occurrence of 127 species of terrestrial vertebrates endemic to the Cerrado, to design a regional network of potential areas that represent all species at least once. The final network has a total of 24 regions widely distributed throughout the biome. We also evaluated these regions in terms of their human occupation by adding a cost for each cell based on 23 variables expressing variation in agricultural, demographic and cattle-ranching patterns on the Cerrado. Our analyses
\end{abstract}

José Alexandre Felizola Diniz-Filho (Corresponding author), Luis Mauricio Bini, Míriam Plaza Pinto*, Guilherme de Oliveira, Bruno de Souza Barreto, Thiago Fernando L.V.B. Rangel ${ }^{\dagger}$, Natalia Mundim Tôrres ${ }^{\ddagger}$ and Rogério Pereira Bastos Departamento de Biologia Geral, ICB, Universidade Federal de Goiás, Cx. P. 131, CEP 74001-970, Goiânia, Goiás, Brazil. E-mail diniz@icb.ufg.br

Levi Carina Terribile Programa de Pós-Graduação em Biologia Animal, Universidade de Brasília, Campus Universitário Darcy Ribeiro, 70910-900, Brasília, DF, Brazil.

Cleiber Marques Vieira ${ }^{\S}$ and Daniel Blamires $₫$ Programa de PósGraduação em Ciências Ambientais, Universidade Federal de Goiás, Campus II, Cx. P. 131, CEP 74001-970, Goiânia, Goiás, Brazil.

Priscilla Carvalho Universidade Estadual de Maringá, Nupelia, Av. Colombo 5790, CEP 87020-900, Maringá, Paraná, Brazil.

${ }^{\star}$ Also at: Universidade Federal do Rio de Janeiro, Rio de Janeiro, Brazil.

${ }^{\dagger}$ Also at: University of Connecticut, Storrs, Connecticut, USA.

${ }^{\ddagger}$ Also at: Jaguar Conservation Fund, Mineiros, Goiás, Brazil.

${ }^{\S}$ Also at: Universidade Estadual de Goiás, Unidade Universitária de Anápolis, Goiás, Brazil.

ॠAlso at: Universidade Estadual de Goiás, Unidade Universitária de Quirinópolis, Goiás, Brazil.

Received 11 December 2006. Revision requested 12 February 2007. Accepted 9 May 2007. showed that conservation efforts should be concentrated in the south and south-east of the biome. This macroecological approach can provide broad guidelines for conservation and define the focus for more local and realistic conservation efforts.

Keywords Biogeography, Brazil, Cerrado, conservation planning, macroecology, optimization, reserve network.

This paper contains supplementary material that can be found online at http://journals.cambridge.org

\section{Introduction}

The Cerrado is the second largest biome in Brazil after 1 the Amazon rainforest and encompasses much environmental heterogeneity at both local and regional scales, characterized by vegetation types dominated by savannahlike ecosystems (Ratter \& Dargie, 1992; Ratter et al., 1996; Klink \& Machado, 2005; Silva et al., 2006). This biome is categorized as a global biodiversity hotspot, with high rates of habitat conversion resulting from recent expansion of soya bean agriculture and cattle ranching threatening many endemic and rare species (Myers et al., 2000; Brooks et al., 2002; Klink \& Machado, 2005; Conservation International, 2008).

Attempts to establish conservation priorities for the Cerrado have hitherto been based on subjective criteria (but see Cavalcanti \& Joly, 2002; Silva \& Bates, 2002; DinizFilho et al., 2004, 2006, 2007). In conservation planning, political and economic interests are often given more weight than scientific criteria and thus many protected areas encompass habitat unsuitable for the maintenance of native species. In addition, the lack or misuse of biological information, even when economic aspects are considered, may lead to suboptimal management strategies (Brito, 2005). Beyond these common problems, lack of detailed data on species distribution and abundance for most groups of organisms in the Cerrado has discouraged the application of systematic conservation planning (sensu Margules \& Pressey, 2000; but see Diniz-Filho et al., 2004, 2006, 2007; Bini et al., 2006). 
However, as advocated elsewhere (Diniz-Filho et al., 2004, 2007), broad scale approaches allow an overview of diversity patterns and thus offer guidelines defined within the framework of conservation biogeography (Whittaker et al., 2005). This hierarchical approach may be particularly useful in poorly known regions that require emergency conservation action because of a combination of high rates of habitat loss and fast human occupation, as is the case with the Brazilian Cerrado.

Patterns of endemism are considered important, explicitly or implicitly, when establishing conservation priorities at multiple spatial scales (Myers et al., 2000), and the Cerrado was categorized as a biodiversity hotspot because of high levels of plant endemism and high threats. These patterns of endemism are related historically to environmental shifts in the region, from savannah-like to dry forests after the Pliocene-Pleistocene transition c. 1.8 million years ago (Silva \& Bates, 2002; Werneck \& Colli, 2006). Silva \& Bates (2002) identified three areas of endemism: the Espinhaço Plateau, the Araguaia River valley, and the Paranã River valley, based mainly on overlap of ranges of endemic bird species. Although animal endemism in the Cerrado is relatively low (c. $10 \%$ of the terrestrial vertebrates are endemic), there are still $>100$ endemic, and mostly rare, species in the region.
In this study we used macroecological data of geographical distributions to evaluate spatial patterns in species richness of endemic terrestrial vertebrates of the Brazilian Cerrado. We evaluate how these patterns can be optimally represented using complementarity-based and irreplaceability procedures, defining which regions of the biome are more important to represent these endemic species. We also find a network that represents all endemics and that, simultaneously, has the minimum amount of human activities within it, based on an evaluation of multiple factors associated with habitat loss. Finally, we evaluate the role of established conservation units in representing these biodiversity patterns.

\section{Methods}

Geographical distributions, measured as extents of occurrence (Gaston, 2003), for a total of 1,213 species of terrestrial vertebrates occurring in the core region of the Brazilian Cerrado, were mapped with a spatial resolution of $1^{\circ}$ on a grid with 181 cells (Fig. 1; see Diniz-Filho et al., 2008, for details of sources). We excluded the isolated and peripheral savannah areas in the Amazon region. Although extents of occurrence are an overestimate of species distributions (Araújo, 2004), at broad spatial scales this is the only

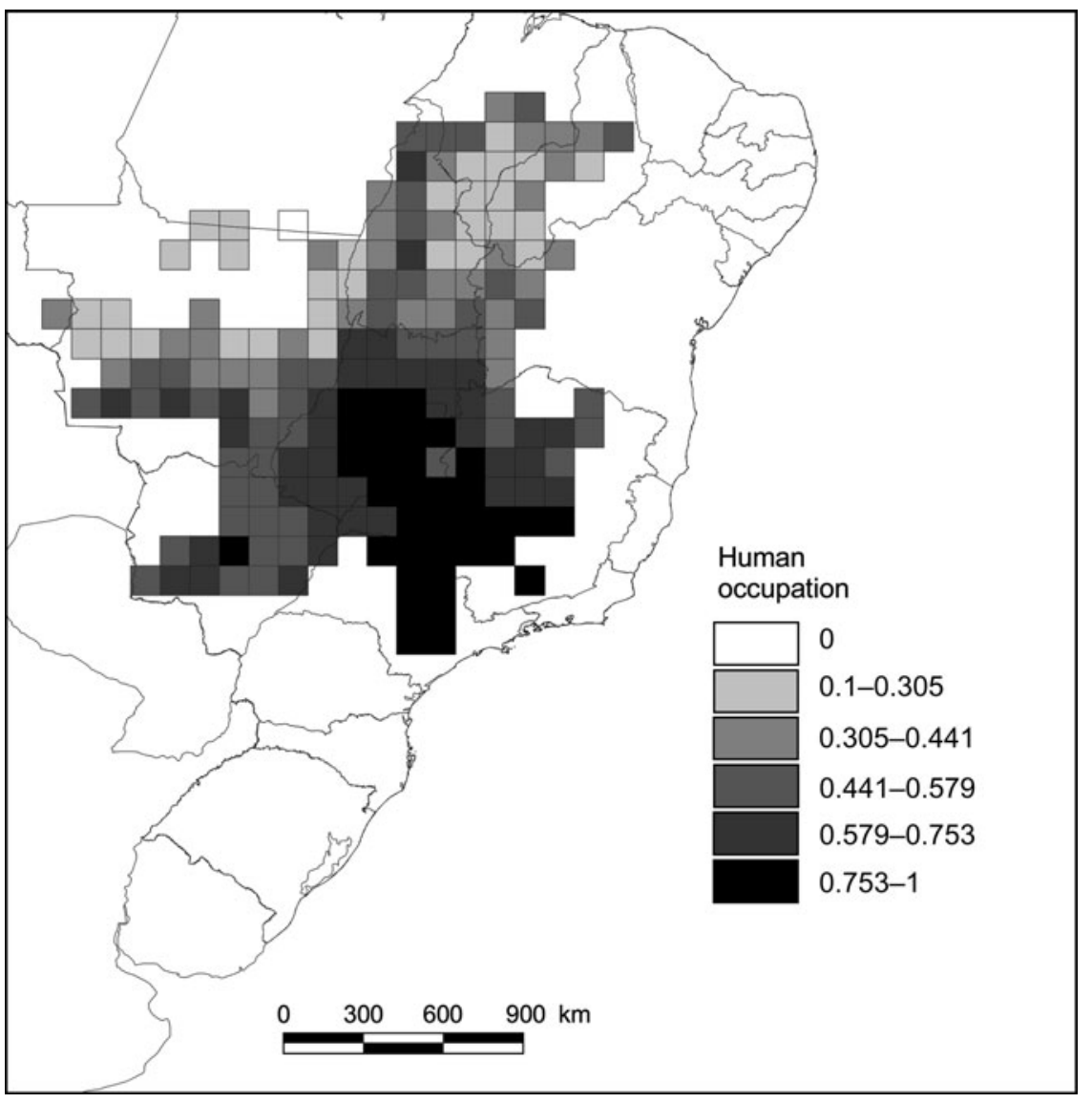

FIG. 1 Spatial patterns of human occupation in the Brazilian Cerrado, defined by the standardized sum of the first three axes from a factor analyses based on 23 socio-economic variables (Rangel et al., 2007; see text for further details). The 181 cells are $1^{\circ}$ latitude and longitude. 
distributional information that can be used for many regions, and particularly those with high biodiversity and low sampling efforts, such as the Neotropics (Bini et al., 2006). Using finer grain sizes may give a false impression of precision and usually increases commission errors (Rondinini et al., 2006). A $1^{\circ}$ grid cell is a compromise that recognizes the limitations of the data but may provide guidelines for detailed studies at finer spatial scales (see also Hulbert \& Jetz, 2007). As Luck (2007) noted ' ...it is important to use a grain size that has, on average, the potential to incorporate both human settlements and adjacent conservation areas because the impact of humans is not confined within settlement boundaries'.

Species lists from Colli et al. (2002), Macedo (2002) and Marinho-Filho et al. (2002) were updated, and construction of range maps was based on both primary and secondary literature. Of the 1,213 species mapped, 127 are endemic to the Cerrado (16 species of mammal, 29 birds, 35 reptiles and 47 amphibians; Appendix). A binary matrix was constructed by recording the presence of these species in each cell, and species richness was the sum of the number of species present in each cell.

Based on the occurrence matrix for the 127 endemic species in the 181 cells we used optimization procedures to select the minimum number of cells necessary to represent all species at least once (Church et al., 1996; Pressey et al., 1997; Possingham et al., 2000; Polasky et al., 2000, 2001; Cabeza \& Moilanen, 2001), the so-called set-covering problem. A simulated annealing algorithm was used to achieve this. It begins with a random set of cells and, for each iteration, swaps sites in and out of that set, measuring the change in cost according to a cost function. The optimization procedure was repeated 100 times, and final networks were obtained after 1,000,000 iterations, implemented in the Site Selection Mode routine of the software SITES (Possingham et al., 2000). A relatively high penalty value of losing a species was set so that all solutions tended to represent all species with a minimum number of cells. Given a large number of possible planning units (cells in our case) within the region of interest, SITES selects those units that, simultaneously, meet the conservation goals (i.e. to represent all species at least once) and minimize cost (by selecting a minimum set of planning units).

Multiple solutions satisfying this representation goal can be obtained by Site Selection Mode and, in this case, they were combined to generate a map that gives the relative importance of each cell in achieving minimum networks. We calculated the frequency of cells across the 100 minimum solutions found by Site Selection Mode as an estimate of the irreplaceability of the cell (Ferrier et al., 2000; Meir et al., 2004). This irreplaceability ranges from o (minimum irreplaceability) to $100 \%$ (maximum irreplaceability), measuring the likelihood that a given cell will need to be protected to ensure all species are represented at least once. A cell with a species that occurs only there will have maximum irreplaceability because there is no chance to conserve this species elsewhere.

We also added a cost for each cell based on 23 variables expressing variation in agricultural, demographic and cattleranching patterns in the Cerrado (IBGE, 2008; see Table 1 of Rangel et al., 2007, for the complete list of variables). Firstly, data entering each cell were calculated by summing or averaging data from 1,054 municipalities whose geopolitical limits lie within the Cerrado's borders. Secondly, we performed a factor analysis (Legendre \& Legendre, 1998) on the resultant matrix ( 23 variables $\times 181$ cells) to reduce the dimensionality of the data and to indicate independent patterns of human occupation in the Cerrado. We used a varimax rotation of scores to minimize the number of variables that have high loadings on each factor and, in this way, simplify their interpretation. We also used the Broken-Stick model as a criterion to retain PCA axes for interpretation: a principal component (axis) is retained if its associated eigenvalue is larger than the value given by a broken-stick null distribution of eigenvalues (see Legendre \& Legendre, 1998, and Peres-Neto et al., 2005, for a detailed explanation). Of three interpretable axes (see Rangel et al., 2007), the first factor axis was positively correlated with variables indicating modern agriculture activities (intensive use of measures to control arable soil erosion, high per capita incomes, high levels of investment in pesticides and biological control, fertilization, and farming machinery, associated with relatively low human population fecundity rates). Variables related to cattle ranching were highly correlated with the second axis (pasture land used for cattle ranching, and bovine herd size). The last interpretable axis was positively correlated with total human population, percentage of population that is rural, and high number of farms with areas $<100$ ha (a surrogate of agricultural landscape fragmentation; see Rangel et al., 2007, for further details).

Thus, Site Selection Mode was run to minimize costs and at the same time force all species to be represented in at least one cell. These costs were expressed both by each factor analysis axis (reflecting different underlying cost assumptions for cattle ranching, modern agriculture or human population density; Rangel et al., 2007) and by the overall sum of these scores, expressing simultaneously multiple dimensions of human occupation in the Cerrado (Fig. 1). Thus, high values of this combined cost indicate cells with high incidence of modern agriculture, cattleranching activities or human population density. Previous studies have used only total human population in optimization models, finding the network that represents all species but has the minimum human population (Chown et al., 2003). However, because of the mode of recent human occupation in the Cerrado, based on rapid expansion of highly technological agriculture and extensive 


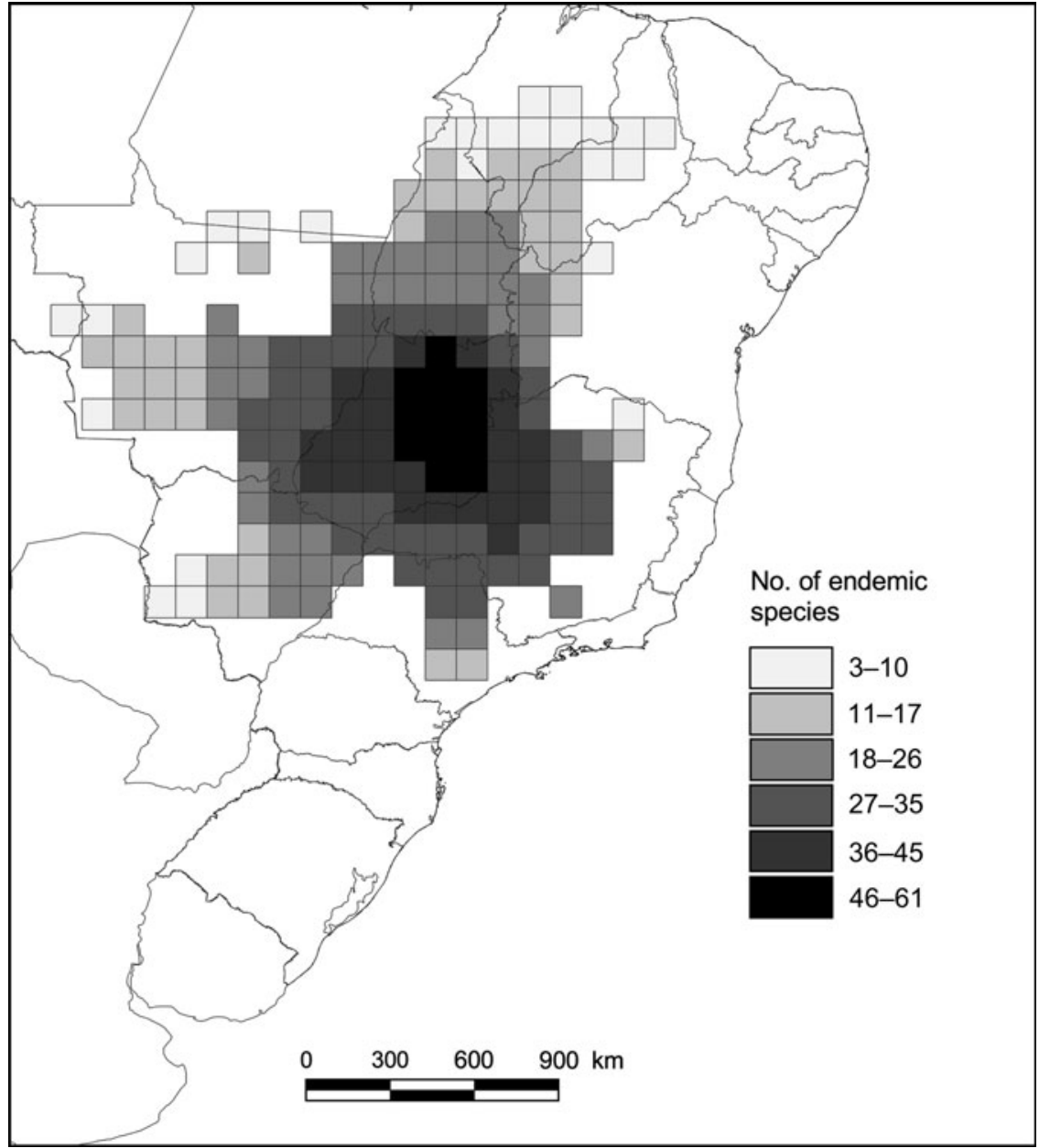

Fig. 2 Number of endemic species of vertebrates (of a total of 127) in each of the $1811^{\circ}$ latitude and longitude cells of the Brazilian Cerrado. cattle-ranching practices (Klink \& Machado, 2005), more complex socio-economic patterns (e.g. cattle ranching and land conversion for soya bean production are not associated with high human population density) need to be included. This allowed us to choose, amongst many possible network solutions, the one that represents all species and whose regions (i.e. cells) are located where there is the smallest possible total human occupation in respect to all these axes of human occupation (sensu Balmford et al., 2001; Araújo, 2003; see also Diniz-Filho et al., 2006).

We performed an evaluation of the efficiency of the conservation system already implemented in the Cerrado in terms of its ability to represent the endemic terrestrial vertebrates. Firstly, we included in our analyses only the 33 units of protection $>10,000$ hectares, which are in 26 cells. We consider a cell is protected if it includes at least one of these large units, and we counted the proportion of the species that were covered by these units (Rodrigues et al., 2004). We then used a randomization test to evaluate if the number of species represented in these 26 cells is different from the values expected by chance alone. To do this we counted the proportion of species covered by 10,000 net- works with 26 cells randomly allocated (Chown et al., 2003; O'Dea et al., 2006). Secondly, we repeated the Site Selection Mode analysis after fixing the protected cells. Thus, Site Selection Mode was used to add more cells to the initial configuration of 26 cells, where necessary, to represent all species in the final system. For instance, if all endemic species are already represented in these 26 initial protected cells, no further increases would be necessary.

\section{Results}

The highest richness of endemic species was found in the central-southern region of the Cerrado, decreasing towards the north-east (Fig. 2). Of the 127 endemic species analysed, 19 occurred in a single cell, and 35 were found in only one or two cells. Thus, the overall range size frequency distribution follows the well-known skewed pattern in which most species are restricted to a few cells (Fig. 3; Gaston, 2003). Because of small geographic ranges, a relatively large number of cells are required to represent all species.

The Site Selection Mode analysis indicated that 24 cells are required to represent all 127 endemic species at least 


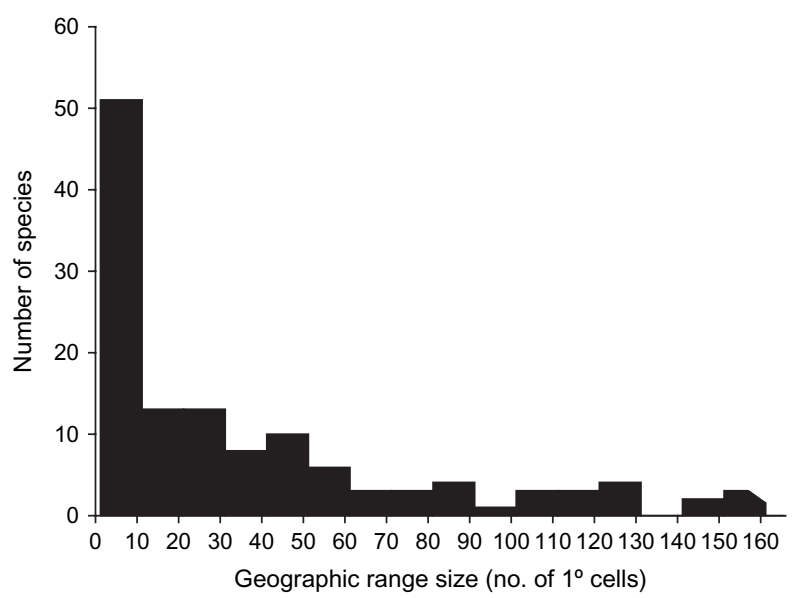

Fig. 3 Frequency distribution of species' range sizes in terms of the $1811^{\circ}$ latitude and longitude cells of the Brazilian Cerrado (Fig. 2).

once. Because of the patterns of extents of occurrence and beta diversity, the levels of representation of most species provided by this network were higher than the minimum target required from the simulated annealing procedure (Fig. 4). For example, $66.9 \%$ of the 127 endemic species were represented more than once in the simulated annealing network and, therefore, they were represented in different areas within their ranges; $14.9 \%$ were represented only once, mainly because they are already restricted to a single cell in the grid.

The frequency of cells across all 100 solutions (i.e. the irreplaceability) was usually low, with only 14 cells being considered highly irreplaceable (Fig. 5). The overall pattern of irreplaceability values reveals that important regions for species representation are widely distributed across the entire Cerrado, although cells with maximum irreplace- ability (i.e. those that appear in all 100 solutions) were concentrated in the south-east.

Despite differences in spatial patterns of human occupation generated by the three factor axes, the site selection solutions found that minimizing each one is similar (Fig. 6). This is expected because most species occur in one or two cells (Fig. 3), restricting the potential representation solutions and decreasing the degree of flexibility of the site selection process. In these solutions, cells are allocated preferentially in the south and south-east, with fewer cells in the north-east, as expected from the irreplaceability patterns.

Randomly selecting 26 cells across the biome allows representation of $89 \pm$ SE 6 species (Fig. 7), which is significantly less than the observed representation of 101 species. The chance of representing these 101 species $(80 \%)$ using 26 cells by chance alone is very low $(\mathrm{P}=0.018)$, suggesting that current location of protected cells is not random with respect to endemism. Despite this relatively high efficiency, when we fixed these cells in the Site Selection Mode analysis, the total number of cells needed to represent all species increases to 43 widely distributed in the biome (Fig. 8).

\section{Discussion}

Spatial patterns in the richness of endemic birds of the Cerrado were described and analysed by Silva \& Bates (2002) with respect to historical processes of broad scale environmental transitions between savannah-like and forest habitats since the Pliocene-Pleistocene transition (see also Silva, 1997). The three areas of endemism they recognized were all inside (or are close to, as with the

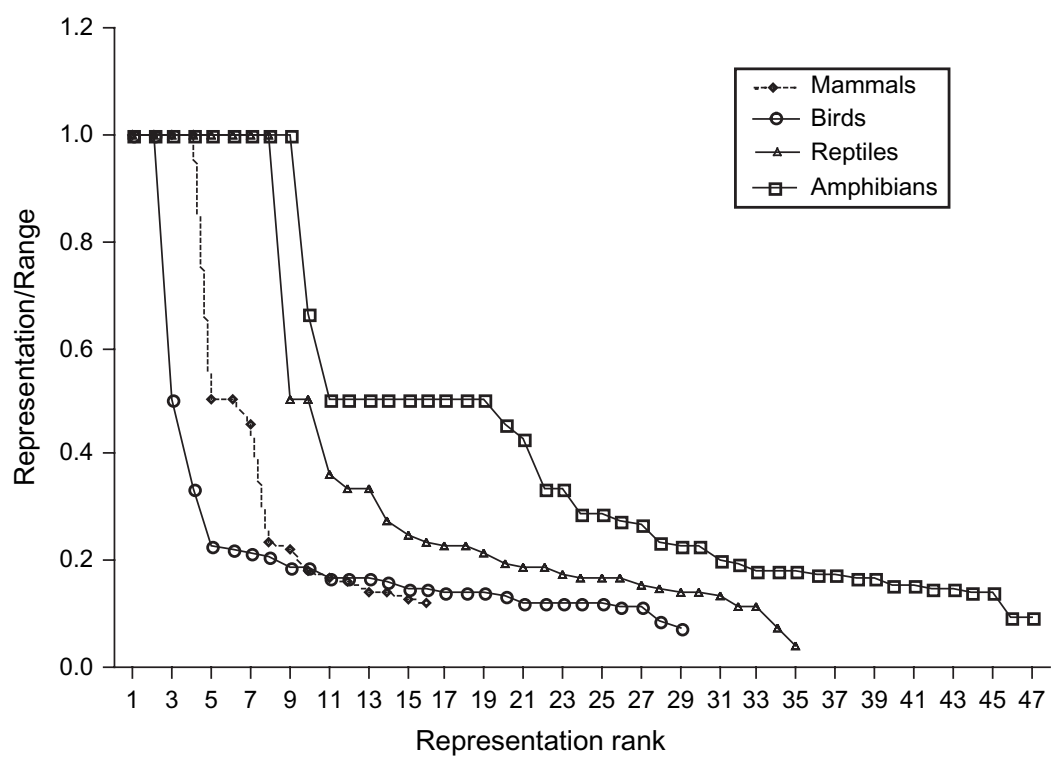

FIG. 4 Rank of representation of the endemic terrestrial vertebrate species of each group (mammal, bird, reptile and amphibian) in the network of $241^{\circ}$ cells that minimizes overall human occupation in the Brazilian Cerrado. Representation is given by the number of cells in the network occupied by the species divided by its total range within the Cerrado. 


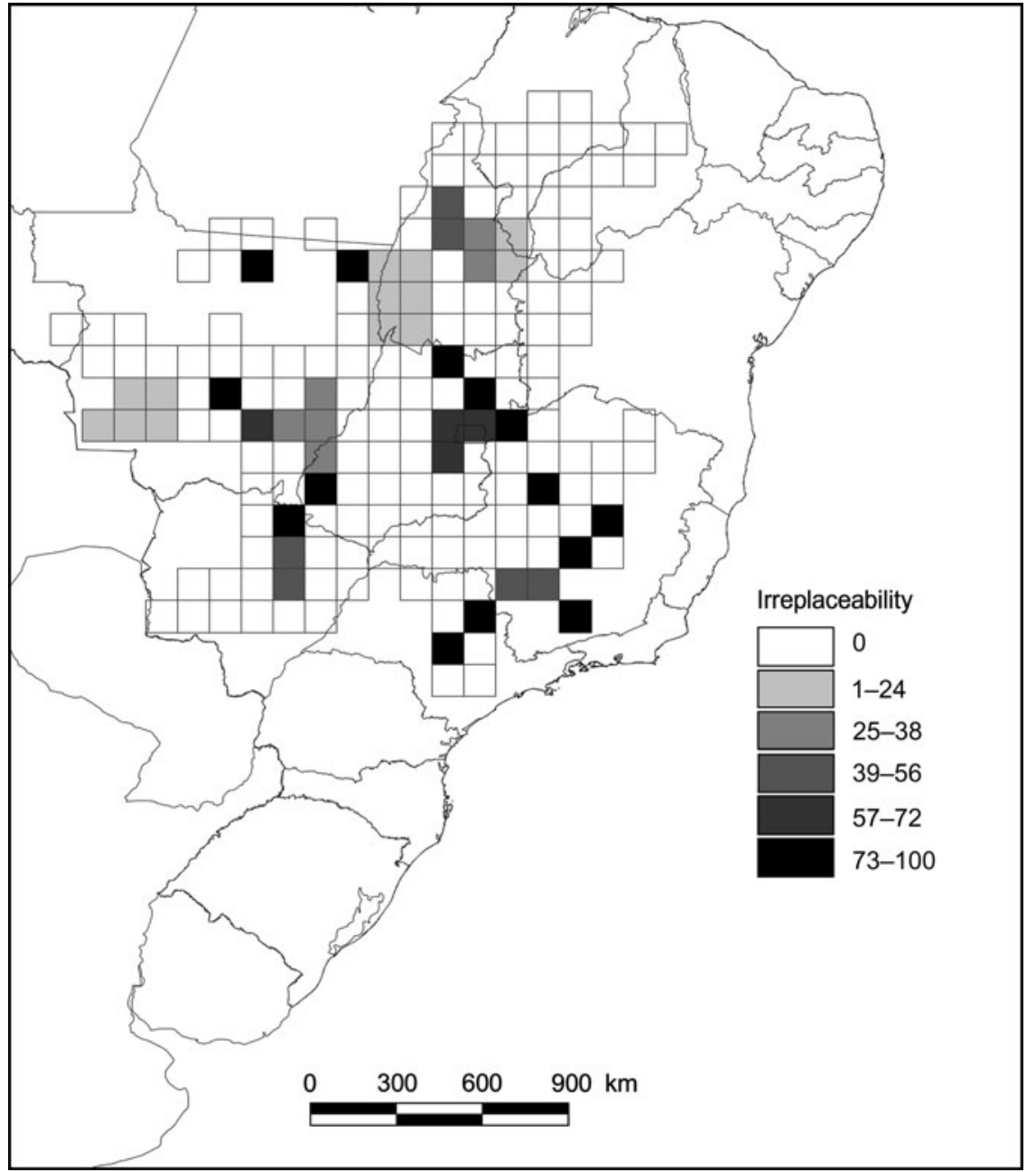

FIG. 5 Spatial patterns of irreplaceability, given by the frequency of $1^{\circ}$ cells of the Brazilian Cerrado in the 100 minimum solutions found by Site Selection Mode, which measures the likelihood that a given cell will need to be protected to ensure all species are represented at least once (see text for details).
Araguaia River valley) the area of high richness found in this study for all vertebrates, in the central south-east of the Cerrado. It is not currently possible to differentiate areas within this general area more clearly because the extents of occurrence used in this study tend to overestimate areas of species occurrence and increase commission errors. However, there is a paucity of faunal inventories, especially for reptiles and amphibians, in the northern Cerrado (Bini et al., 2006) and thus further inventories would probably expand the pattern of endemic areas northwards (Bini et al., 2006).

The patterns of endemic vertebrate species richness of the Cerrado are similar to expectations of the so-called mid domain effect proposed by Colwell \& Lees (2000; see Hawkins \& Diniz-Filho, 2002; Zapata et al., 2003; Colwell et al., 2004; Hawkins et al., 2005, for discussions), in which random overlap of ranges creates high richness in the middle of a study area. However, under certain conditions, the patterns resulting from a mid domain effect could be a result of stochastic dispersion and local extinction, as described by Hubbell's (2001) neutral dynamics (Rangel \& Diniz-Filho, 2005). In Hubbell's model richness patterns are generated by a random balance between aggregation of species due to distance-mediated dispersal and random extinction in local sampling units. Further investigations of this issue are necessary, especially linking potential mid domain effect patterns and processes of habitat shifts in a historical context (Silva \& Bates, 2002). However, there is strong sampling bias in the Cerrado, with a concentration of researchers in the centre of the biome (in the urban centres of Brasilia and Goiânia), which could artificially generate a mid domain effect.

Despite the difficulties of inferring evolutionary (i.e. processes that occurred during the Pliocene-Pleistocene transition) and ecological (i.e. current stochastic processes of dispersion and local extinction) mechanisms to explain richness patterns in the Brazilian Cerrado, the urgency of conservation issues in the biome dictates that conservation planning must be performed using currently available knowledge. Here we defined reserve networks by optimal solutions based on extents of occurrence, which provide a general description of currently known distributional patterns. Although this approach is likely to generate high levels of commission errors (Gaston \& Rodrigues, 2002) 

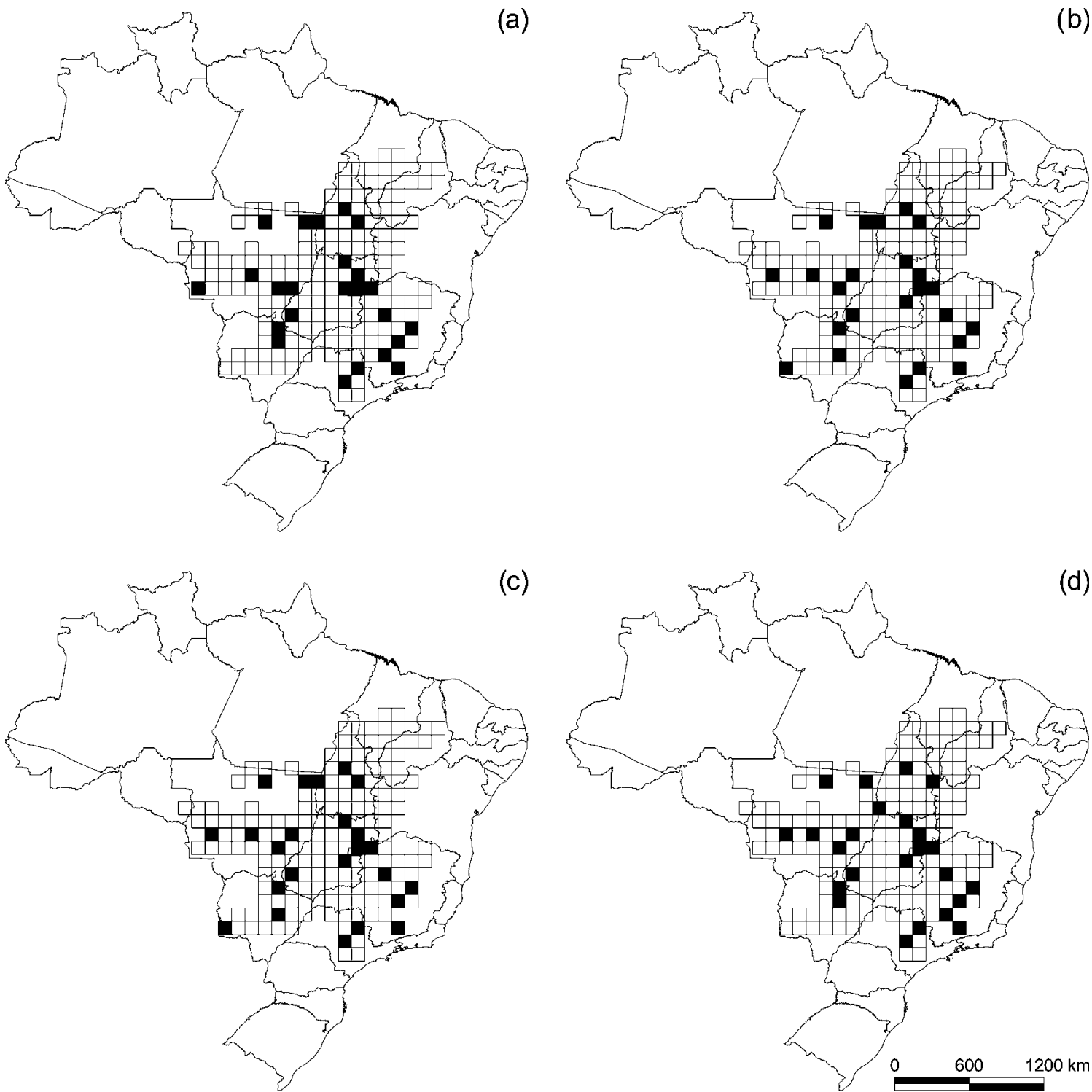

Fig. 6 Spatial patterns of selected $1^{\circ}$ cells of the Brazilian Cerrado in the Site Selection Mode analysis (see text for details) that represent all endemic terrestrial vertebrates and that, at the same time, (a) minimize overall human occupation (i.e. the standardized sum of the three PCA axes), (b) minimize land use by modern agriculture (i.e. the first PCA axis), (c) cattle ranching (i.e. the second PCA axis), and (d) human demography (i.e. the third PCA axis).

there are advantages to using it because of the relatively low level of available knowledge of the distribution of the vertebrates of the Cerrado. Also, under a conservation biogeography framework (Whittaker et al., 2005), and using relatively large grain sizes (i.e. $1^{\mathrm{o}}$ of latitude and longitude), commission errors tend to be at an acceptable level (Rondinini et al., 2006). This is especially true if one considers that our main purpose is to define a hierarchical approach for conservation planning that starts at a broad, regional scale and allows further, more detailed investigations and development of planning strategies at a finer spatial scale (Diniz-Filho et al., 2004, 2007). An alternative approach to deal with lack of detailed inventories is to use niche-based modelling strategies to define distribution patterns better (Araújo \& Guisan, 2006; Araújo \& New, 2007), which in turn can be used for conservation planning. However, most of the endemic species of the Cerrado are recorded in only a few places, making it difficult to apply these techniques in a systematic way.

Our analyses showed that conservation efforts for representing endemic terrestrial vertebrates of the Brazilian Cerrado should be concentrated in at least 24 cells of $1^{\circ}$ latitude and longitude, covering seven states (Goiás, Minas Gerais, Tocantins, Bahia, Maranhão, Mato Grosso, and Mato Grosso do Sul). Because we used extents of occurrence and expected patterns of beta diversity, multiple 


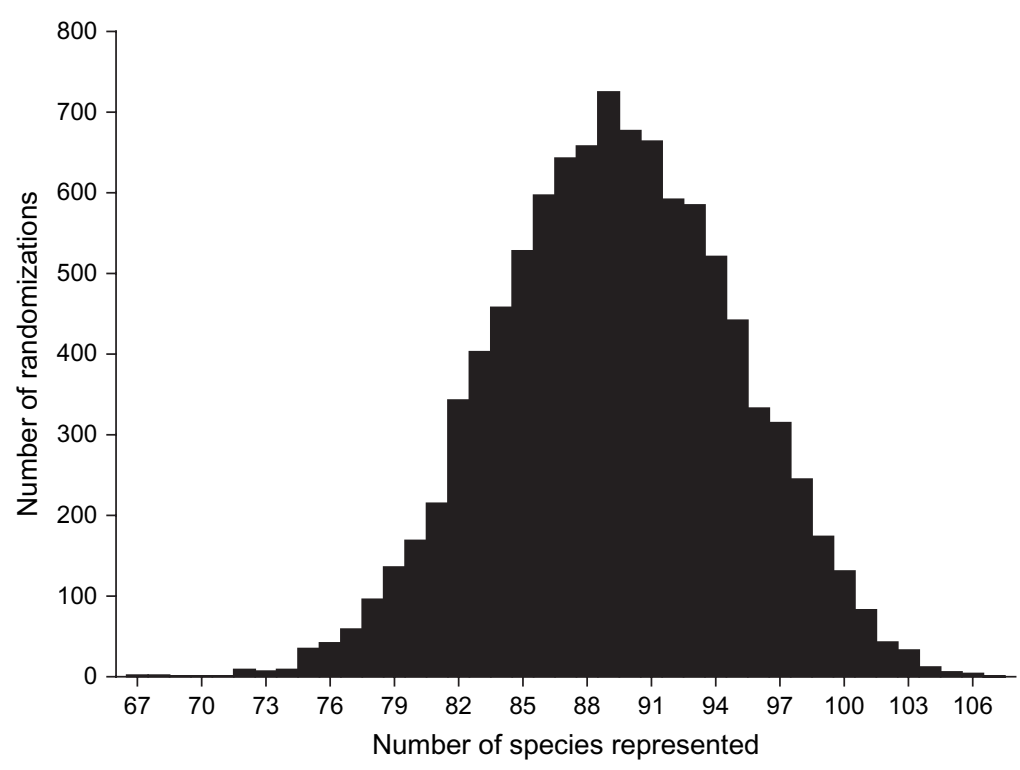

FIG. 7 Frequency distribution of number of represented species in 10,000 randomly generated networks with $241^{\circ}$ cells, showing the low efficiency of species representation with a randomly defined network.

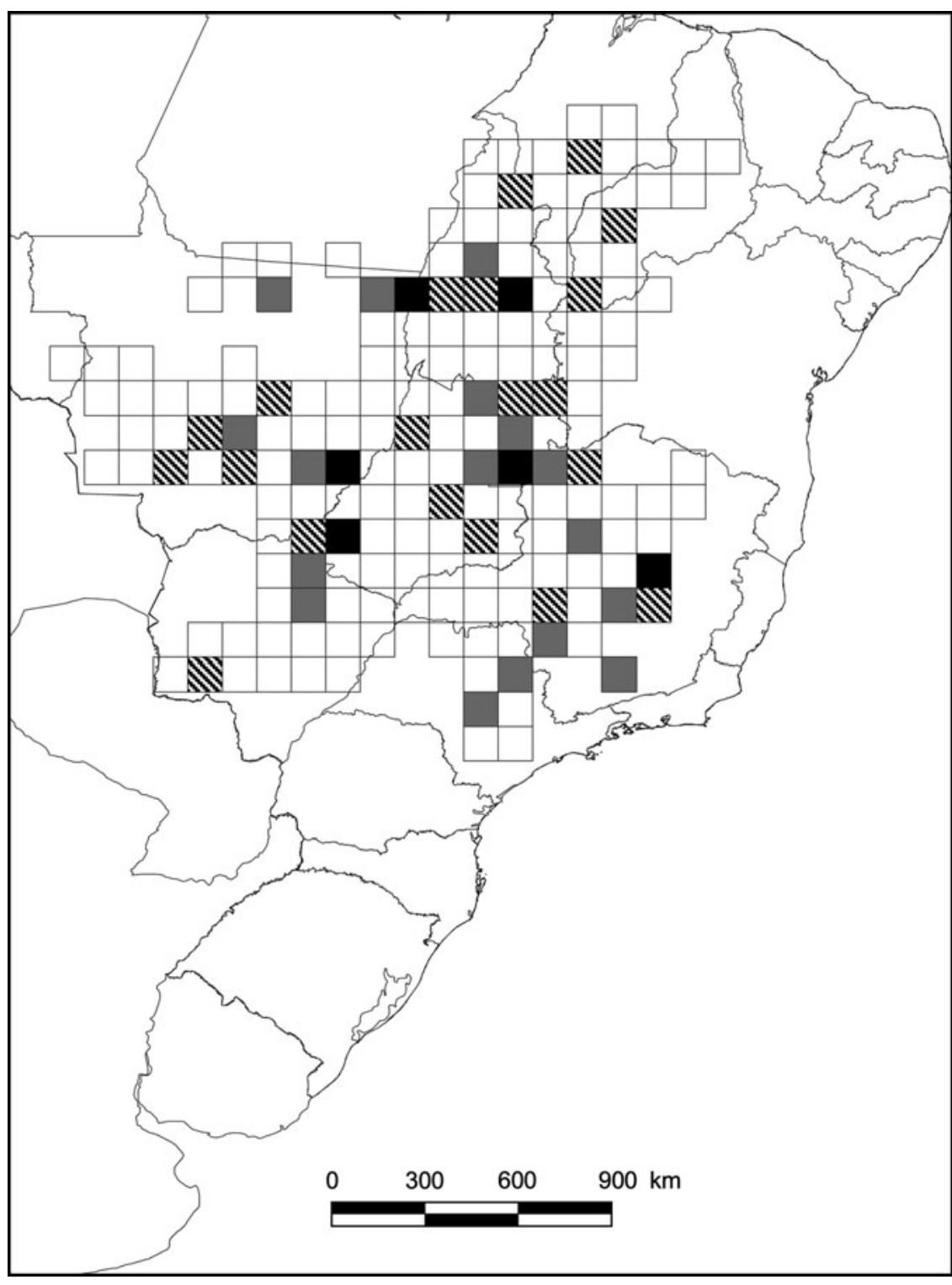

FIG. 8 Site Selection Mode analysis after fixing the 26 cells of the Brazilian Cerrado that already contain conservation units in the final solution, maximizing species representation and minimizing human occupation. Grey cells were selected by Site Selection Mode, black cells already contain conservation units, and hatched cells indicate overlap between them. 
solutions to represent all species are always available, giving a certain level of flexibility in the system, although many areas with maximum irreplaceability are concentrated in the central and south-east. This is expected because solutions are constrained, in geographical terms, by a number of small-range endemic species (mainly anurans) whose distributions tend to be concentrated in this area.

In Brazil large biomes have been considered as broad scale targets for conservation actions, and in the case of the Cerrado this is reinforced by its status as a global biodiversity hotspot (Cavalcanti \& Joly, 2002). An important outcome of our analyses is that to consider the Cerrado biome as a unique and coherent unit it will be necessary to establish a national geopolitical coordination for conservation planning to minimize the loss of efficiency that would occur if conservation areas were to be independently established in each state (Rodrigues \& Gaston, 2002). Even more importantly, the geographical coverage of the conservation units already established in the biome overlap c. $80 \%$ of the endemic vertebrate ranges. On the one hand, this is a conservative measure because we only considered conservation units $>10,000$ ha, and small units can also protect species. On the other hand, our macroecological analysis does not ensure that species are found within conservation units, both because these are usually much smaller than our grain size and because we are not able to analyse if each conservation unit has suitable habitat for each species. Also, our Site Selection Mode analysis shows that, even though a high proportion of endemic species is represented by the current system of protected areas, the remaining species would require a large number of new areas to be protected. Thus, although geographical gaps are relatively small when data is analysed at broad geographical scales, our preliminary conservation biogeography approach supports previous claims that conservation throughout this biome needs to be improved by adding more protected areas (Silva \& Bates, 2002).

We included in our optimization models a variable (sum of the scores of the first three factor analysis axes) that comprises different types of human activities but that is statistically independent. Thus, the selected areas (Fig. 6) are those with the lowest human population densities and are also unsuitable for agriculture and cattle ranching, which are, in general, the main factors that threaten biodiversity in the Cerrado (Klink \& Machado, 2005; Rangel et al., 2007). Nevertheless, the Site Selection Mode solutions that we used are always similar under the alternative scenarios expressing human occupation because of the restricted range of endemic Cerrado species. Conservation efforts should therefore be targeted independently of the type of human activities that are expected to threaten diversity.

Our analysis provides guidelines for future conservation and research programmes for defining priority regions for conservation in the Brazilian Cerrado. The next step will be to generate more detailed species distributions at multiple spatial scales, using niche-based modelling approaches. More intensive and detailed local sampling within each region can then be used to ensure the persistence and longterm maintenance of important areas for conservation and, at the same time, facilitate a better understanding of patterns of richness and endemism. We anticipate that our findings can drive conservation planning by guiding and coordinating sampling efforts at local scales and, after such validation and refinement, by advising government authorities and decision makers where it will be more efficient to purchase land that meets a given conservation goal.

\section{Acknowledgements}

Financial support for this study came from a PRONEX programme of the Conselho Nacional de Desenvolvimento Cientifico $(\mathrm{CNPq})$ \& Tecnológico and Secretaria de Ciência \& Tecnologia (no. 23234156). JAFDF, LMB and RPB were also partially supported by other CNPq projects (nos 300762/94-1, 300367/96-1, 400381-97.4), and NMT, GO, LCT, TFLVBR, MPP and PC were supported by Coordenação para Aperfeiçoamento de Pessoal de Ensino Superior graduate fellowships.

\section{References}

Araújo, M.B. (2003) The coincidence of people and biodiversity in Europe. Global Ecology \& Biogeography, 12, 5-12.

Araújo, M.B. (2004) Matching species with reserves - uncertainties from using data at different resolutions. Biological Conservation, 118, 533-538.

Araújo, M.B. \& Guisan, A. (2006) Five (or so) challenges for species distribution modelling. Journal of Biogeography, 33, 1677-1688.

Araújo, M.B. \& New, M. (2007) Ensemble forecasting of species distributions. Trends in Ecology and Evolution, 22, 42-47.

Balmford, A., Moore, J.L., Brooks, T., Burgess, N., Hansen, L.A., Williams, P. et al. (2001) Conservation conflicts across Africa. Science, 291, 2616-2619.

Bini, L.M., Diniz-Filho, J.A.F., Rangel, T.F.L.V.B., Bastos, R.P. \& Pinto, M.P. (2006) Challenging Wallacean and Linnaean shortfalls: knowledge gradients and conservation planning in a biodiversity hotspot. Diversity and Distributions, 12, 475-482.

BRITO, D. (2005) The importance of sound biological information and theory for ecological economics studies valuing Brazilian biodiversity: a response to Mendonça et al. (2003). Ecological Economics, 55, 5-10.

Brooks, T.M., Mittermeier, R.A., Mittermeier, C.G., Fonseca, G.A.B., Rylands, A.B., Konstant, W.R. et al. (2002) Habitat loss and extinction in the hotspots of biodiversity. Conservation Biology, 16, 909-923.

Cabeza, M. \& Moilanen, A. (2001) Design of reserve networks and the persistence of biodiversity. Trends in Ecology \& Evolution, 16, 242-248.

Campbell, J.A. \& Lamar, W.W. (2004) The Venomous Reptiles of the Western Hemisphere, Vol. I \& II. Comstock Publishing Associates, New York, USA. 
Cavalcanti, R.B. \& Joly, C.A. (2002) Biodiversity and conservation priorities in the Cerrado region. In The Cerrados of Brazil: Ecology and Natural History of a Neotropical Savanna (eds P.S. Oliveira \& R.J. Marquis), pp. 351-367. Columbia University Press, New York, USA.

Chown, S.L., van Rensburg, B.J., Gaston, K.J., Rodrigues, A.S.L. \& VAN JAARSVELD, A.S. (2003) Energy, species richness, and human population size: conservation implications at a national scale. Ecological Applications, 13, 1233-1241.

Church, R.L., Stoms, D.M. \& Davis, F.W. (1996) Reserve selection as a maximal covering location problem. Biological Conservation, $76,105-112$.

Colli, G.R., Bastos, R.P. \& Araújo, A.F.B. (2002) The character and dynamics of the Cerrado herpetofauna. In The Cerrado of Brazil: Ecology and Natural History of a Neotropical Savanna (eds P.S. Oliveira \& R.J. Marquis), pp. 223-241. Columbia University Press, New York, USA.

Colwell, R.K., Rahbek, C. \& Gotelli, N.J. (2004) The middomain effect and species richness patterns: what have we learned so far? American Naturalist, 163, E1-E23.

Conservation International (2008) Biodiversity Hotspots. Http:// www.biodiversityhotspots.org [accessed 11 February 2008].

Cowell, R. \& Lees, D. (2000) The mid-domain effect and the longitudinal dimension of continents. Trends in Ecology \& Evolution, 15, 288-289.

del Hoyo, J., Elliot, A. \& Sargatal, J. (1992) Handbook of the Birds of the World. Vol. 1: Ostrichs to Ducks. Lynx Edicions, Barcelona, Spain.

del Hoyo, J., Elliot, A. \& Sargatal, J. (1994) Handbook of the Birds of the World. Vol. 2: New World Vultures to Guineafowl. Lynx Edicions, Barcelona, Spain.

del Hoyo, J., Elliot, A. \& Sargatal, J. (1996) Handbook of the Birds of the World. Vol. 3: Hoatzin to Auks. Lynx Edicions, Barcelona, Spain.

del Hoyo, J., Elliot, A. \& Sargatal, J. (1997) Handbook of the Birds of the World. Vol. 4: Sandgrouse to Cuckoos. Lynx Edicions, Barcelona, Spain.

del Hoyo, J., Elliot, A. \& Sargatal, J. (1999) Handbook of the Birds of the World. Vol. 5: Barn Owls to Hummingbirds. Lynx Edicions, Barcelona, Spain.

del Hoyo, J., Elliot, A. \& Sargatal, J. (2001) Handbook of the Birds of the World. Vol. 6: Mousebirds to Hornbills. Lynx Edicions, Barcelona, Spain.

del Hoyo, J., Elliot, A. \& Sargatal, J. (2002) Handbook of the Birds of the World. Vol. 7: Jacamars to Woodpeckers. Lynx Edicions, Barcelona, Spain.

Diniz-Filho, J.A.F., Bastos, R.P., Rangel, T.F.L.V.B., Bini, L.M., Carvalho, P. \& Silva, R.J. (2005) Macroecological correlates and spatial patterns of anuran description dates in the Brazilian Cerrado. Global Ecology and Biogeography, 14, 469-477.

Diniz-Filho, J.A.F., Bini, L.M., Pinto, M.P., Rangel, T.F.L.V.B, Carvalho, P. \& Bastos, R.P. (2006) Anuran species richness, complementarity and conservation conflicts in Brazilian Cerrado. Acta Oecologica, 29, 9-15.

Diniz-Filho, J.A.F., Bini, L.M., Rangel, T.F.L.V.B, Carvalho, P., Pinto, M.P., Couto, M.S.D.S. et al. (2007) Conservation biogeography of anurans in Brazilian Cerrado. Biodiversity and Conservation, 16, 997-1008.

Diniz-Filho, J.A.F., Bini, L.M., Vieira, C.M., Blamires, D., Terribile, L.C., Bastos, R.P. et al. (2008) Spatial patterns of terrestrial vertebrate species richness in the Brazilian Cerrado. Zoological Studies, 47 (in press).

Diniz-Filho, J.A.F., Bini, L.M., Vieira, C.M., Souza, M.C., Bastos, R.P., Brandẽo, D. et al. (2004) Spatial patterns in species richness and priority areas for conservation of anurans in the Cerrado region, Central Brazil. Amphibia-Reptilia, 25, 63-75.

Eisenberg, J.F. \& Redford, K.H. (1999) Mammals of the Neotropics. Vol. 3: The Central Neotropics. The University of Chicago Press, Chicago, USA.

Elith, J., Graham, C.H., Anderson, R.P., Dudik, M., Ferrier, S., Guisan, A. et al. (2006) Novel methods improve prediction of species' distributions from occurrence data. Ecography, 29, 129151.

Emmons, L.H. \& Feer, F. (1990) Neotropical Rainforest Mammals: A Field Guide. The University of Chicago Press, Chicago, USA.

Ferrier, S., Pressey, R.L. \& Barrett, T.W. (2000) A new predictor of the irreplaceability of areas for achieving a conservation goal, its application to real-world planning, and a research agenda for further refinement. Biological Conservation, 93, 303-325.

Fonseca, G.A.B., Herrmann, G., Leite, Y.L.R., Mittermeier, R.A., Rylands, A.B. \& Patton, J.L. (1996) Lista anotada dos mamíferos do Brasil. Conservation International \& Fundação Biodiversitas, Belo Horizonte, Brazil.

Frost, D. (1985) Amphibian Species of the World. Allen Press, Lawrence, USA.

Gaston, K.J. (2003) The Structure and Dynamics of Geographic Ranges. Oxford University Press, Oxford, UK.

Gaston, K.J. \& Rodrigues, A.S.L. (2003) Reserve selection in regions with poor biological data. Conservation Biology, 17, 188-195.

Gorenflo, L.J. \& Brandon, K. (2006) Key human dimensions of gaps in global biodiversity conservation. BioScience, 56, 723-731.

Hawkins, B.A. \& Diniz-Filho, J.A.F. (2002) The mid-domain effect cannot explain the diversity gradient of Nearctic birds. Global Ecology and Biogeography, 11, 419-426.

Haw kins, B.A., Diniz-Filho, J.A.F. \& Weis, A.E. (2005) The middomain effect and diversity gradients: is there anything to learn? American Naturalist, 166, 140-143.

Huв веLL, S.P. (2001) The Unified Neutral Theory of Biodiversity and Biogeography. Princeton University Press, Princeton, USA.

Hulbert, A.H. \& Jetz, W. (2007) Species richness, hotspots, and the scale dependence of range maps in ecology and conservation. Proceedings of the Natural Academy of Sciences, 104, 13384-13389.

IBGE (Instituto Brasileiro de Geografia e Estatística) (2008) Http:// www.ibge.gov.br [accessed 11 February 2008].

Isler, M.L. \& Isler, P.R. (1999) The Tanagers: Natural History, Distribution and Identification. Smithsonian Institution Press, Washington, DC, USA.

Juniper, T., Parr, M. \& Franklin, K. (1998) Parrots: A Guide to Parrots of the World. Yale University Press, New Haven, USA.

KLinK, C.A. \& MaChado, R.B. (2005) Conservation of the Brazilian Cerrado. Conservation Biology, 19, 707-713.

Legendre, P. \& Legendre, L. (1998) Numerical Ecology, 2nd edition. Elsevier, Amsterdam, The Netherlands.

Luck, G.W. (2007) The relationships between net primary productivity, human population density and species conservation. Journal of Biogeography, 34, 201-212.

MACEDO, R.H.F. (2002) The avifauna: ecology, biogeography and behavior. In The Cerrados of Brazil: Ecology and Natural History of a Neotropical Savanna (eds P.S. Oliveira \& R.J. Marquis), pp. 242-263. Columbia University Press, New York, USA.

Margules, C.R. \& Pressey, R.L. (2000) Systematic conservation planning. Nature, 405, 243-253.

Marinho-Filho, J.S., Rodrigues, F.H.G. \& Juarez, K.M. (2002) The Cerrado mammals: diversity, ecology, and natural history. In The Cerrados of Brazil: Ecology and Natural History of a Neotropical Savanna (eds P.S. Oliveira \& R.J. Marquis), pp. 266-284. Columbia University Press, New York, USA. 
Meir, E., Andelman, S. \& Possingham, H.P. (2004) Does conservation planning matter in a dynamic and uncertain world? Ecology Letters, 7, 615-622.

Myers, N., Mittermeier, R.A., Mittermeier, C.G., Fonseca, G.A.B. \& KENT, J. (2000) Biodiversity hotspots for conservation priorities. Nature, 403, 853-858.

Nogueira, C.C. (2001) New records of squamate reptiles in central Brazilian Cerrado II: Brasilia region. Herpetological Review, 32, 285-287.

O’Dea, N., Araújo, M.B. \& Whittaker, R.J. (2006) How well do important bird areas represent species and minimize conservation conflict in the tropical Andes? Diversity and Distributions, 12, 205214.

Peres-Neto, P.R., Jackson, D.A. \& Somers, K.M. (2005) How many principal components? Stopping rules for determining the number of non-trivial axes revisited. Computational Statistics and Data Analysis, 49, 974-997.

Polasky, S., Camm, J.D., Solow, A.R., Csuti, B., White, D. \& DING, R. (2000) Choosing reserve networks with incomplete species information. Biological Conservation, 94, 1-10.

Polasky, S., Csuti, B., Vossler, C.A. \& Meyer, S.M. (2001) A comparison of taxonomic distinctness versus richness as criteria for setting conservation priorities for North American birds. Biological Conservation, 97, 99-105.

Possingham, H., Ball, I. \& Andelman, S. (2000) Mathematical methods for identifying representative reserve networks. In Quantitative Methods for Conservation Biology (eds S. Ferson \& M. Burgman), pp. 291-306. Springer-Verlag, New York, USA.

Pressey, R.L., Possingham, H.P. \& Day, J.R. (1997) Effectiveness of alternative heuristic algorithms for identifying indicative minimum requirements for conservation reserves. Biological Conservation, 80, 207-219.

Rangel, T.F.L.V.B. \& Diniz-Filho, J.A.F. (2005) An evolutionary tolerance model explaining spatial patterns in species richness under environmental gradients and geometric constraints. Ecography, 28, 253-263.

Rangel, T.F.L.V.B., Bini, L.M., Diniz-Filho, J.A.F., Pinto, M.P., Carvalho, P. \& Bastos, R.P. (2007) Human development and biodiversity conservation in Brazilian Cerrado. Applied Geography, 27, 14-27.

Ratter, J.A. \& Dargie, T.C.D. (1992) An analysis of the floristic composition of 26 Cerrado areas in Brazil. Edinburgh Journal of Botany, 49, 235-250.

Ratter, J.A., Bridgewater, S., Atrinson, R. \& Ribeiro, J.F. (1996) Analysis of the floristic composition of the Brazilian Cerrado vegetation II: comparison of the woody vegetation of 98 areas. Edinburgh Journal of Botany, 53, 153-180.

Ridgely, R.S. \& Tudor, G. (1989) The Birds of South America. Vol. 1: The Oscine Passerines. University of Texas Press, Austin, USA.

Ridgely, R.S. \& Tudor, G. (1994) The Birds of South America. Vol. 2: The Suboscine Passerines. University of Texas Press, Austin, USA.

Rodrigues, A.S.L. \& Gaston, K.J. (2002) Rarity and conservation planning across geopolitical units. Conservation Biology, 16, 674682.

Rodrigues, A.S.L., Andelman, S.J., Bakarr, M.I., Boitani, L., Brooks, T.M., Cowling, R.M. et al. (2004) Effectiveness of the global protected area network in representing species diversity. Nature, 428, 640-643.

Rondinini, C., Wilson, K.A., Boitani, L., Grantham, H. \& Possingham, H.P. (2006) Trade-offs of different types of species occurrence data for use in systematic conservation planning. Ecology Letters, 9, 1136-1145.
Silva, J.F., Farinas, M.R., Felfili, J.M. \& Klink, C.A. (2006) Spatial heterogeneity, land use and conservation in the Cerrado region of Brazil. Journal of Biogeography, 33, 524-535.

Silva, J.M.C. (1995) Birds of the Cerrado region, South America. Steenstrupia, 21, 69-92.

Silva, J.M.C. (1996) Distribution of Amazonian and Atlantic birds in gallery forests of the Cerrado region, South America. Ornitologia Neotropical, 7, 1-18.

SilVA, J.M.C. (1997) Endemic bird species and conservation in the Cerrado region, South America. Biodiversity and Conservation, 6, $435-450$.

Silva, J.M.C. \& B ATES, J.M. (2002) Biogeographic patterns and conservation in the South American Cerrado: a tropical savanna hotspot. BioScience, 52, 225-233.

Valdujo, P.H. \& Nogueira, C. (2001) New records of Squamata reptiles in the Central Brazilian Cerrado: Emas National Park region. Herpetological Review, 32, 128-130.

VAnZolini, P.E. (1997) The silvestrii species group of Amphisbaena, with the description of two new Brazilian species (Reptilia: Amphisbaenia). Papéis Avulsos de Zoologia, 40, 65-85.

Vanzolini, P.E. (2002) An aid to the identification of the South American species of Amphisbaena (Squamata, Amphisbaenidae). Papéis Avulsos de Zoologia, 42, 351-362.

Werneck, F.P. \& Colli, G.R. (2006) The lizard assemblage from seasonally dry tropical forest enclaves in the Cerrado biome, Brazil, and its association with the Pleistocene arc. Journal of Biogeography, 33, 1983-1992.

Whittaker, R.J., Araújo, M.B., Jepson, P., Ladle, R.J., Watson, J.E.M. \& Willis, K.J. (2005) Conservation biogeography: assessment and prospect. Diversity and Distributions, 11, 3-23.

Wilson, D.E. \& Reeder, D.M. (2005) Mammal Species of the World. A Taxonomic and Geographic Reference. 3 rd edition. Smithsonian Institution Press, Washington, DC, USA.

Zapata, F.A., Gaston, K.J. \& Chown, S.L. (2003) Mid-domain models of species richness gradients: assumptions, methods and evidence. Journal of Animal Ecology, 72, 677-690.

\section{Appendix}

The appendix for this article is available online at http:// journals.cambridge.org

\section{Biographical sketches}

This paper is part of a Conselho Nacional de Desenvolvimento Cientifico \& Tecnológico-PRONEX project to develop and apply optimization and spatial methods to find conservation priority areas in the Cerrado region of central Brazil, coordinated by José Alexandre Felizola Diniz-Filho, Luis Mauricio Bini and Rogerio Pereira Bastos of the Universidade Federal de Goiás. The team of authors included $\mathrm{PhD}$ and MSc students in ecology, evolution, animal biology and environmental sciences (MÍrIaM Plaza Pinto, Levi Carina Terribile, Guilherme de Oliveira, Bruno de Souza Barreto, Priscilla Carvalho, Thiago Fernando L.V.B. Rangel and Natalia Mundin Tôrres) and Cleiber Marques Vieira and Daniel Blamires, who now work at the Universidade Estadual de Goiás. All members of the team brought their various areas of expertise and taxonomic knowledge to this study. 